\title{
Information System Policy of Web-based Patient Safety Incident Reporting Information System at RSJ Prof Dr. Soerojo Magelang
}

\author{
* Setyo Purnomo, ** Aris Puji Widodo, *** Yuliani Setyaningsih \\ *,**,*** Master of Public Health, Health Management Information System, \\ Universitas Diponegoro, Semarang, Jawa Tengah, Indonesia
}

Email : setyopurnomo@gmail.com

\begin{abstract}
To provide security to their patients, healthcare providers use a system for patient safety which includes risk reporting and analysis of incidents, identification and management of risks, and the ability to learn about events that have occurred. According to the 2017 patient safety data at Prof. Dr. Soerojo Psychiatric Hospital, 7\% of patient safety incidents at the hospital required a Root Cause Analysis. To aid the process, an online information system is necessary. This research was qualitative research that used the waterfall method for the information syntax. This involved planning, analysis, design, implementation, and system. From there, the data was then evaluated based on its accessibility, completeness, accuracy, and speed. The qualitative data was gathered through questionnaires, in-depth interviews, and unstructured interviews with selected informants. 26 informants were involved in this research, this included the reporters, the Patient Safety (KPRS) Team, and the hospital management board. Results of the would then produce recommendations on how to handle the problems found. Based on the data gathered, we discovered that after the application of the information system, the hospital experienced a 53.8\% increase in patient safety.
\end{abstract}

Keywords: Information System, RCA, KPRS, Incident

\section{INTRODUCTION}

To provide security to their patients, healthcare providers use a system for patient safety which includes risk reporting and analysis of incidents, identification and management of risks, and the ability to learn about events that have occurred so that they know what should or should not be is done to guarantee patient safety.[1] Law Number 44 of 2009 in Indonesia on Hospitals, Article 2, and Article 3 point b stated that the Hospital must provide guarantees for patient safety by providing optimal service.[1]

From 2011 to 2017, Prof. Dr. Soerojo Psychiatric Hospital has recorded the data incident for patient safety. The patient safety data was then used to report incidents once every three months. The reports then would be graded to determine whether a simple investigation or Root Cause Analysis (RCA) is necessary.[1] In 2017, only 7\% (4 of the 54 incidents) of the incidents reported required an RCA.

The reporting system at Prof. Dr. Soerojo Psychiatric Hospital was a manually generated one, therefore there was inconsistencies in the reporting.[1] This meant that the management was unable to monitor the incidences and to follow-up on the completion of recommendations. As a result, it is possible for the incident to occur again in the future, which would reduce patient safety. Therefore, to prevent the reoccurrence of the incident, a new system that can aid in reporting the incidents and the follow-up process is necessary, a dynamic online system.[1]

\section{Research Methods}

This was qualitative research that used the waterfall method for the information syntax. This involved planning, analysis, design, implementation, and system. From there, the data was then evaluated based on its accessibility, completeness, accuracy, and speed. There was also a pre-test and post-test to discover whether the new information system would improve or impair the quality of information based on those 4 variables. The qualitative data was gathered through questionnaires, in-depth interviews, and unstructured interviews with selected informants. 26 staff of the Prof. Dr. Soerojo Psychiatric Hospitals were involved in the study. We selected currently active and knowledgeable informants to collect more precise data and aid the evaluation.

\section{Running System Problems}

Three parties were responsible for the reports, i.e. the 
reporter, the Patient Safety (KPRS) team, and the management team. The reporter was obligated to report the incidents and perform an investigation if the results of the evaluation were blue or green or perform an RCA if the results were yellow or red. The KPRS team would perform the RCA. Results of the investigations and RCA would then be reported to the management to be followed-up.

Hospital already has a patient safety system, however, whenever there was an incident, the reporting process did not fully comply with the standard procedures, which must be complete within 2 days ( $2 \times 24$ hours) from the documentation to the submission of the report. This delay became a problem for all the related parties since it would affect the speed of the investigation, therefore increasing the possibility of recurrences and its reduce patient safety.

\section{Systems Analysis}

After the in-depth interviews, the following problemsolving recommendations were obtained:

\begin{tabular}{|c|c|}
\hline Description & Proposed solution \\
\hline $\begin{array}{l}\text { Unreported and delayed } \\
\text { reporting of events }\end{array}$ & $\begin{array}{l}\text { To create prompt incident reporting, and easy information system is } \\
\text { necessary. }\end{array}$ \\
\hline Lengthy data analysis & $\begin{array}{l}\text { To process information quickly and accurately, a database must be } \\
\text { created. }\end{array}$ \\
\hline Limited access to reporting & Create a Smartphone-accessible information system. \\
\hline $\begin{array}{l}\text { No standard procedures for } \\
\text { reporting }\end{array}$ & Create a standard procedure for reporting. \\
\hline $\begin{array}{l}\text { Management cannot monitor } \\
\text { incidents and recommendations }\end{array}$ & $\begin{array}{l}\text { Procure an instrument panel to monitor the incidents and its } \\
\text { recommendations, therefore enabling the management to monitor and } \\
\text { evaluate the process. }\end{array}$ \\
\hline
\end{tabular}

Based on the problems and its recommendations stated in table 1, the following system must be established.

\begin{tabular}{ll}
\multicolumn{1}{c}{ Table 2. Environment System } \\
\hline \multicolumn{1}{c}{ Description } & \multicolumn{1}{c}{ Specifications } \\
\hline System Development Model & The waterfall development method \\
\hline Operating Systems & Microsoft Windows \\
\hline Programming Language & PHP (Personal Home Page/ Hypertext Preprocessor) \\
\hline Database & My SQL \\
\hline
\end{tabular}

As stated in the table above, the model used in the information systems development was the waterfall method. This method is capable of generating a system that would suit the user's needs, however, the program writing must be completed before it is implemented.[1] The information system used in the program was Microsoft Windows, which was chosen because of its familiarity. The programming language used the Personal Home Page (PHP) language that is a free client-server program language system used by various web-based applications.[1]

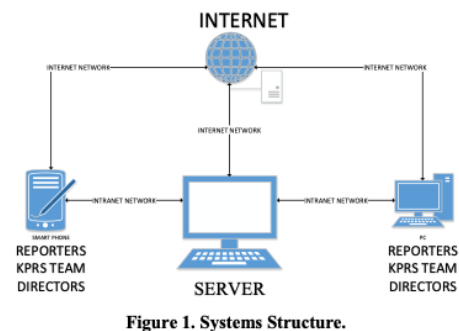

\section{Systems Design}

The input used for this system was data that would be entered into the system, and the output was the reports in the form of tables and graphics that would later be posted on the information board that would be monitored by the management. The parties involved in the patient safety system at Prof. Dr. Soerojo Psychiatric Hospital Magelang were:

\section{Reporters}

The reporters would input patient data, details on the incident, and divide the results into four categories, the blue, green, yellow, or red category. Blue and green categories would only require a simple investigation, while yellow and red categories required a more comprehensive investigation or an RCA. The reporter would also enter the complete data of the follow-up recommendations into the system, whether it was completed or forwarded to other departments (See figure 2).

\section{IDQ}

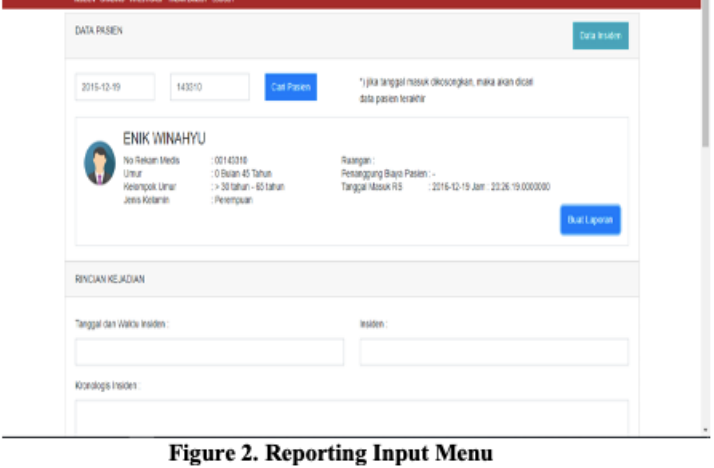

\section{KPRS Team}

The KPRS team can also act as another reporter. However, this team would be able to add the RCA recommendations which were separated based on the needs of the user and can monitor the development of the incident and its follow-up process.

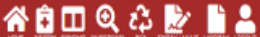

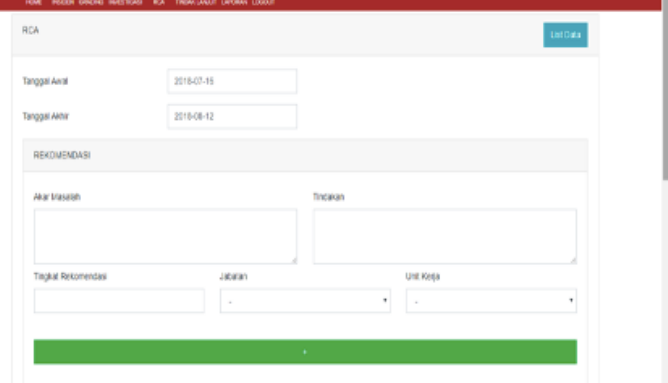

Figure 3. RCA Input Menu 


\section{Management/Directors}

The Board of Directors only monitors the information board, the recommendation process, and the follow-up process. The data that they handle cal be used to support any decision taken.[1]

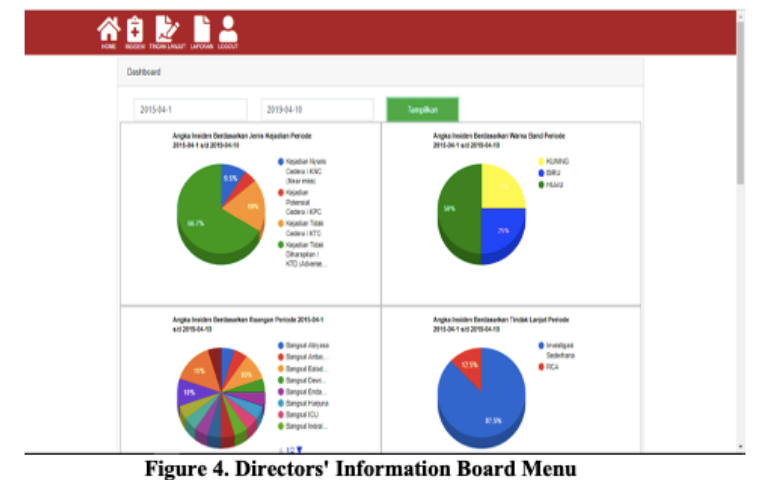

\section{Evaluation of the Systems}

The results of the information quality testing before and after the system was established is visible in table 3. According to table 3 , the quality of information improved from $41.3 \%$ to $95 \%$ after the information system was established, which meant that there was a $53.8 \%$ increase. On the Likert scale, it meant that the information system upgraded the scale from Negative to Positive.[1] This indicated that patient safety had improved with the application of the information system and the program was a success.[1]

\begin{tabular}{|c|c|c|c|c|c|c|c|}
\hline \multirow{2}{*}{\multicolumn{2}{|c|}{ STATEMENT }} & \multicolumn{2}{|c|}{ Average Before } & \multicolumn{2}{|c|}{ Average After } & \multicolumn{2}{|c|}{ Difference } \\
\hline & & Results & $\%$ & Results & $\%$ & Results & $\%$ \\
\hline A & Accessibility & 1,87 & $37,3 \%$ & 4,93 & $98,7 \%$ & 3,07 & $61,3 \%$ \\
\hline B & Completeness & 2,40 & $48,0 \%$ & 4,73 & $94,7 \%$ & 2,33 & $46,7 \%$ \\
\hline $\mathrm{C}$ & Accuracy & 2,05 & $41,0 \%$ & 4,67 & $93,3 \%$ & 2,62 & $52,3 \%$ \\
\hline D & Speed & 1,93 & $38,7 \%$ & 4,67 & $93,3 \%$ & 2,73 & $54,7 \%$ \\
\hline & AVERAGE & \multicolumn{2}{|c|}{$41,3 \%$} & \multicolumn{2}{|c|}{$95,0 \%$} & \multicolumn{2}{|c|}{$53,8 \%$} \\
\hline
\end{tabular}

\section{Conclusion}

Reportation of patient safety at Prof. Dr. Soerojo Psychiatric Hospital that resulted in recommendations that were then applied has complied with the regulations Law Number 44 of 2009 in Indonesia on Hospitals, Article 2, and Article 3 point b. And an information system that facilitates its reporting and monitoring of the results was necessary. What type of data that was included in the system would be based on what type of output (results) was required by the Hospital, and the system-generated reports and information boards for the management that were expected to reduce the number of patient safety violations. As a result of the use of the information system to patient safety incidents, the number of incidents reduced and patient satisfaction increased by $53.8 \%$. This meant that an information system is a valuable addition to a hospital's development and should be applied to all hospitals.

\section{REFERENCES}

1. American Occupational Health Conference (AOHC). Definition of Patient Safety. ACOEM. 2016.

2. Cowing M., Davino-Ramaya CM., Ramaya K., Szmerekovsky J. Health care delivery performance: service, outcomes, and resource stewardship. Perm J. 2009;13(4):72-78.

3. Komite Akreditasi Rumah Sakit. Standard Nasional Akreditasi Rumah Sakit Edisi I. Jakarta; 2017

4. Mukhofifah, U., Migunani. Perancangan Sistem Pelaporan Keuangan Berbasis Web (studi Kasus pada PT Emkl Tirtasari Abadi Sejahtera Semarang). Jurnal Teknologi Informasi dan Komunikasi. 2015;6(2):2087-0868

5. Talpur, MSH. The Appliance Pervasive of Internet of Things in Healthcare Systems. International Journal of Computer Science Issues. 2013;10(1):1694-0784.

6. Alshamrani, A., Bahattab, A. A Comparison Between Three SDLC Models Waterfall Model, Spiral Model, and Incremental/Iterative Model. International Journal of Computer Science Issues. 2015;12(1):1692-0814

7. Adenuga, I., Akinyede, O., Akinsowon, O. Development of a Cost-Effective Telemedicine Services for People Affected with CardioVascular Diseases in the Rural Area: A Case Study of Iwo Local Government. International Journal of Computer Science Issues. 2014;11(6):1694-0814

8. Davis, GB. Kerangka Dasar Sistem Informasi Manajemen. Palembang: Maxikom;2013

9. Jan, L., Wetmore, A. CDC Coffee Break: Using Likert Scales in Evaluation Survey Work. National Center for Chronic Disease Prevention and Health Promotion USA. 2012.

10. Montazemi, A.R. Factors Affecting Information Satisfaction in the Context of the Small Business Environment. MIS Quarterly,1988; V 12(2), pp. 236-256 